\title{
Protecting P-glycoprotein at the blood- brain barrier from degradation in an Alzheimer's disease mouse model
}

\author{
Yujie Ding ${ }^{1}$, Yu Zhong ${ }^{1}$, Andrea Baldeshwiler ${ }^{2}$, Erin L. Abner ${ }^{1,5}$, Björn Bauer ${ }^{3}$ and Anika M. S. Hartz ${ }^{1,4,6^{*}}$ (1)
}

\begin{abstract}
Background: Failure to clear $A \beta$ from the brain is partly responsible for $A \beta$ brain accumulation in Alzheimer's disease (AD). A critical protein for clearing $A \beta$ across the blood-brain barrier is the efflux transporter P-glycoprotein (P-gp). In $A D, P$-gp levels are reduced, which contributes to impaired $A \beta$ brain clearance. However, the mechanism responsible for decreased P-gp levels is poorly understood and there are no strategies available to protect P-gp. We previously demonstrated in isolated brain capillaries ex vivo that human $A \beta 40$ (hA $\beta 40$ ) triggers P-gp degradation by activating the ubiquitin-proteasome pathway. In this pathway, hA $\beta 40$ initiates P-gp ubiquitination, leading to internalization and proteasomal degradation of P-gp, which then results in decreased P-gp protein expression and transport activity levels. Here, we extend this line of research and present results from an in vivo study using a transgenic mouse model of AD (human amyloid precursor protein (hAPP)-overexpressing mice; Tg2576).
\end{abstract}

Methods: In our study, hAPP mice were treated with vehicle, nocodazole (NCZ, microtubule inhibitor to block P-gP internalization), or a combination of NCZ and the P-gp inhibitor cyclosporin A (CSA). We determined P-gp protein expression and transport activity levels in isolated mouse brain capillaries and A levels in plasma and brain tissue.

Results: Treating hAPP mice with $5 \mathrm{mg} / \mathrm{kg}$ NCZ for 14 days increased P-gp levels to levels found in WT mice. Consistent with this, P-gp-mediated hAß42 transport in brain capillaries was increased in NCZ-treated hAPP mice compared to untreated hAPP mice. Importantly, NCZ treatment significantly lowered hAß40 and hAß42 brain levels in hAPP mice, whereas $\mathrm{hA} 40$ and $\mathrm{hA} \beta 42$ levels in plasma remained unchanged.

Conclusions: These findings provide in vivo evidence that microtubule inhibition maintains P-gp protein expression and transport activity levels, which in turn helps to lower hAß brain levels in hAPP mice. Thus, protecting P-gp at the blood-brain barrier may provide a novel therapeutic strategy for $A D$ and other $A \beta$-based pathologies.

Keywords: Blood-brain barrier, P-glycoprotein, Alzheimer's disease, Brain capillaries, Amyloid beta, Ubiquitinproteasome system

\section{Introduction}

One hallmark of Alzheimer's disease (AD) is the accumulation of neurotoxic amyloid beta $(A \beta)$ in the brain [1]. This accumulation of soluble and insoluble $A \beta$

*Correspondence: anika.hartz@uky.edu

${ }^{6}$ University of Kentucky Sanders-Brown Center on Aging, $800 \mathrm{~S}$ Limestone, Lexington, KY 40536, USA

Full list of author information is available at the end of the article forms contributes to neurodegeneration and dementia observed in $\mathrm{AD}$ [2]. Increasing evidence from recent studies indicates that $A \beta$ brain accumulation is, in part, due to impaired $A \beta$ clearance from the brain across the blood-brain barrier into the blood [3-5]. Results from multiple studies show that the ATP-driven efflux transporter $\mathrm{P}$-glycoprotein (P-gp) transports $\mathrm{A} \beta$, and thus, is involved in clearing $A \beta$ from the brain [6-14]. In this regard, Callaghan et al. used different software docking 
programs to predict P-gp interactions with $A \beta$. The obtained models suggest that $A \beta 40$ vertically enters the central cavity of P-gp [7]. Several studies using tissue samples from $\mathrm{AD}$ patients have shown that blood-brain barrier P-gp protein expression levels are decreased compared to cognitive normal individuals [15-18]. Recent data show a $53 \%$ reduction $(p<0.01)$ in $\mathrm{P}$-gp protein levels in capillaries from $\mathrm{AD}$ patient brain samples compared to samples from control individuals [19]. Consistent with decreased P-gp expression levels, results of PET studies indicate compromised P-gp activity levels in AD patients $[20,21]$. Thus, existing studies support the conclusion that blood-brain barrier P-gp protein expression and transport activity are decreased in AD. Results from our own studies using a transgenic mouse AD model (human amyloid precursor protein (hAPP)-overexpressing mice; Tg2576) support these observations and suggest a link between high hA $\beta$ levels and decreased brain capillary P-gp expression and activity levels in $\mathrm{AD}[9,22$, 23]. Moreover, we found that hA $\beta 40$ causes $P$-gp degradation in brain capillaries [22, 23]. Specifically, we demonstrated that hA $\beta 40$ triggers P-gp degradation through activation of the ubiquitin-proteasome pathway: first, P-gp is ubiquitinated; second, P-gp is internalized; and finally, P-gp is degraded by the proteasome [22, 24]. In a recent study we showed that preventing P-gp ubiquitination by inhibiting the ubiquitin-activating enzyme E1 protects blood-brain barrier P-gp expression and activity levels and lowers hA $\beta$ brain levels in young hAPP mice [23]. Here, we extend our work and show that dosing 8-week old hAPP mice with the potent microtubule depolymerization inhibitor nocodazole (NCZ) protects $\mathrm{P}$-gp protein expression and transport activity and lowers hA $\beta$ brain levels.

Thus, protecting P-gp from internalization and degradation at the blood-brain barrier could be one strategy to improve $A \beta$ clearance from the brain.

\section{Materials and methods}

\section{Experimental design and statistical analysis}

Sample sizes (i.e., animal numbers, brain capillary sample size, number of liver tissue samples) were based on power analyses of preliminary data and past published work [9, 22, 23, 25]. Sample size and the number of repetitions are reported in the Results section and the corresponding figure legends.

Results are presented as mean \pm SEM, or percent change, as indicated. One-way analysis of variance, with factor treatment group, was used to assess mean differences in outcomes. Tukey's HSD post-hoc test was used to preserve the family-wise Type 1 error rate at $5 \%$. Post hoc tests were not performed when the omnibus F statistic was not significant. Statistical analyses were completed using SAS 9.4 ${ }^{\circledR}$ (SAS Institute, Inc.; Cary, NC, USA).

\section{Animals}

The Institutional Animal Care and Use Committee at the University of Minnesota (Protocol \#1110A05865, principal investigator; PI: Hartz, AMS) approved all animal experiments, which were conducted in accordance with AAALAC regulations, the Guide of the Care and Use of Laboratory Animals of the NIH, and the US Department of Agriculture Animal Welfare Act.

Male wild type mice (WT; RRID: IMSR_TAC:2789; $\mathrm{n}=10)$ and male transgenic hAPP-overexpressing mice (Tg2576 strain; 129S6.CgTg(APPSWE2576Kha; RRID:IMSR_TAC:2789; $\mathrm{n}=45)$ were acquired from Taconic Farms (Germantown, NY, USA). Mice were received at age 8-12 weeks and were housed individually in an AAALAC-accredited temperature-and-humidity-controlled vivarium $\left(23{ }^{\circ} \mathrm{C}, 35 \%\right.$ relative humidity, $12 \mathrm{~h}$ light-dark cycle) and allowed to habituate to their environment for two weeks prior to experiments. Mice had ad libidum access to tap water and standard rodent feed (Harlan Teklad Chow 2918, Harlan Laboratories Inc., Indianapolis, NJ, USA). Mice used for experiments were 10-14 weeks old and had a mean body weight of $27.4 \pm 1.1 \mathrm{~g}($ mean $\pm \mathrm{SD})$ and $27.6 \pm 2.7 \mathrm{~g}($ mean $\pm \mathrm{SD})$ for WT and hAPP strains, respectively.

\section{Chemicals}

Antibodies against $\beta$-actin (ab8226; RRID: AB_306371), human A $\beta 40$ (ab12265; RRID:AB_298985), human A $\beta 42$ (ab12267; RRID:AB_298987), as well as cyclosporin A (CSA; ab120114) were purchased from Abcam (Cambridge, MA, USA). Modified Dulbecco's phosphate buffered saline (DPBS) with $0.9 \mathrm{mM} \mathrm{Ca}{ }^{2+}$ and $0.5 \mathrm{mM}$ $\mathrm{Mg}^{2+}$ was purchased from HyClone (Logan, UT, USA). Complete $^{\mathrm{TM}}$ protease inhibitor was purchased from Roche (Mannheim, Germany). C219 antibody against P-gp was purchased from ThermoFisher (MA126528; RRID:AB_795165; Waltham, MA, USA). Fluorescein$\mathrm{hA} \beta_{42} \quad$ [fluorescein-A $\left.\beta_{(1-42)}\right]$ was purchased from rPeptide (Bogart, GA, USA). [N-(4-nitrobenzofurazan7-yl)-D-Lys8]-cyclosporin A (NBD-CSA) was customsynthesized by R. Wenger (Basel, Switzerland; [26]). PSC833 was a kind gift from Novartis (Basel, Switzerland). Nocodazole, the ALT Assay Kit (MAK052), CelLytic $^{\text {TM }}$ M, Ficoll ${ }^{\circledR}$ PM 400, bovine serum albumin and all other chemicals were purchased at the highest grade from Sigma-Aldrich (St. Louis, MO, USA).

\section{NCZ dosing}

Mice were randomly divided into four treatment groups (Group 1: WT mice treated with vehicle, $\mathrm{n}=10$; Group 
2: hAPP mice treated with vehicle, $\mathrm{n}=15$; Group 3: hAPP mice treated with nocodazole (NCZ), $\mathrm{n}=15$; and Group 4: hAPP mice treated with cyclosporin A (CSA) and $\mathrm{NCZ}, \mathrm{n}=15$ ). Mice were treated for a total of 14 days; the dosing regimens for NCZ and CSA are shown in Table 1. The dosing regimen and length of the treatment are based on our previously published study and preliminary experiments using NCZ [23]. Briefly, mice in Groups 1 and 2 were treated daily with vehicle (i.p.) every three days for the entire duration of the experiment. Mice in Groups 3 and 4 were treated with $5 \mathrm{mg} / \mathrm{kg}$ of $\mathrm{NCZ}$ (i.p.) every 3 days (days $1,4,7,10$, and 13). On days when no NCZ was given, mice in Group 3 were treated with vehicle (p.o.) and mice in Group 4 were treated with $25 \mathrm{mg} /$ kg CSA (p.o.).

\section{Blood and tissue collection}

At the end of the 14-day treatment period, all mice were euthanized by $\mathrm{CO}_{2}$ inhalation and decapitated; brain tissue, trunk blood, and liver were collected from each animal. Blood was stored in heparinized tubes and plasma was extracted from blood by centrifugation at $5000 \mathrm{~g}$ for 5 min at $4{ }^{\circ} \mathrm{C}$. Brain and liver tissue were frozen in liquid nitrogen at the time of collection and stored at $-80{ }^{\circ} \mathrm{C}$ until further analysis.

\section{ALT assay}

Alanine aminotransferase activity (ALT) in liver tissue lysate was measured using an ALT activity kit (MAK052; Sigma-Millipore, St. Louis, MO, USA) according to the manufacturer's instructions. Briefly, from each mouse $40 \mathrm{mg}$ of collected liver tissue were homogenized in 300 $\mu \mathrm{l}$ of ALT Assay Buffer using a Power Gen 125 tissue homogenizer (Thermo Fisher Scientific, Hampton, NH, USA). Homogenized liver samples were centrifuged at $15,000 \mathrm{~g}$ for $15 \mathrm{~min}$ at $4{ }^{\circ} \mathrm{C}$. Supernatant containing ALT from each liver sample was diluted 1:100 for ALT activity determination. $20 \mu \mathrm{l}$ of the diluted samples was pipetted in duplicates onto a 96-well microplate. Wells were treated with ALT Master Mix solution. Changes in colorimetric intensity was measured at $570 \mathrm{~nm}$ over $30 \mathrm{~min}(5$ min reading intervals, $37^{\circ} \mathrm{C}$ ) using a Synergy ${ }^{\mathrm{TM}} \mathrm{H} 1$ Hybrid Multi-Mode Reader (BioTek, Winooski, VT, USA).

The amount of generated pyruvate, a measure of ALT activity, was determined using a standard curve. ALT activity was calculated using Eq. (1).

$$
\text { ALTActivity }=\frac{(\text { nmolofALT } \times \text { DilutionFactor })}{\left(T_{\text {final }}-T_{\text {initial }}\right) \times(\text { VolumeofSample })}
$$

ALT activity is reported as $\mathrm{nmole} / \mathrm{min} / \mathrm{ml}=$ milliunit $/$ $\mathrm{mL}(\mathrm{mU} / \mathrm{ml})$, where one milliunit $(\mathrm{mU})$ of ALT is defined as the amount of enzyme that generates 1.0 nmole of pyruvate per minute at $37^{\circ} \mathrm{C}$.

\section{Tissue harvest and brain capillary isolation}

Brain capillaries were isolated as previously described $[22,23,27]$. Following euthanasia with $\mathrm{CO}_{2}$, brains were collected, dissected, and cleaned of meninges. Frontal cortex tissue $(\sim 10 \mathrm{mg} /$ brain) was collected, snap frozen in liquid nitrogen, and stored at $-80{ }^{\circ} \mathrm{C}$ for $\mathrm{A} \beta$ analysis. The remaining brain tissue was homogenized in $\mathrm{Ca}^{2+}$ / $\mathrm{Mg}^{2+}$-containing DPBS supplemented with $5 \mathrm{mM}$ D-glucose and $1 \mathrm{mM}$ sodium pyruvate. The brain homogenate was mixed with a $15 \%$ Ficoll $\rightarrow$ PM 400 solution and centrifuged at $5,800 \mathrm{~g}$ for $20 \mathrm{~min}$ at $4^{\circ} \mathrm{C}$ to yield capillary-containing pellets. The pellets were separated and resuspended in 1\% BSA-DPBS solution and the capillary suspension was filtered through a $300 \mu \mathrm{m}$ nylon mesh and then passed through a glass bead column (glass bead diameter: $0.45-0.5 \mathrm{~mm}$ ) with $1 \%$ BSA-DPBS. Capillaries were washed off the glass beads with $1 \%$ BSA-DPBS. The resulting capillary suspension was centrifuged at $1,500 \mathrm{~g}$ for $3 \mathrm{~min}$ at $4^{\circ} \mathrm{C}$ and the pellet was washed three times with DPBS. Isolated capillaries were used for transport experiments, isolation of capillary crude membranes, or stored for later analysis at $-80^{\circ} \mathrm{C}$.

\section{Capillary Crude membrane isolation}

Capillary crude membranes were obtained from freshly isolated brain capillaries as described in previous studies [27]. Isolated brain capillaries were homogenized in a cell lysis buffer (CellLytic ${ }^{\mathrm{TM}} \mathrm{M}$, Sigma-Aldrich, St. Louis, MO, USA) containing Complete ${ }^{\mathrm{TM}}$ protease inhibitor

Table 1 Treatment schedule

\begin{tabular}{l} 
Group \\
\begin{tabular}{|l|l|l|l|l|l|l|l|l|l|l|l|l|l|l|l|}
\hline & \multicolumn{10}{c|}{ Dosing Regimen (Days) } \\
\hline 1) WT & 1 & 2 & 3 & 4 & 5 & 6 & 7 & 8 & 9 & 10 & 11 & 12 & 13 & 14 \\
\hline 2) hAPP & & & & & & & & & & & & & & \\
\hline 3) hAPP-NCZ & & & & & & & & & & & & & & \\
\hline 4) hAPP-NCZ/CSA & & & & & & & & & & & & & \\
\hline
\end{tabular} \\
\hline
\end{tabular}


(Sigma-Aldrich, St. Louis, MO, USA). The capillary homogenate was centrifuged at 10,000 $\mathrm{g}$ for $15 \mathrm{~min}$ at 4 ${ }^{\circ} \mathrm{C}$ to separate organelles and cellular debris. The supernatant was then centrifuged at $100,000 \mathrm{~g}$ for $90 \mathrm{~min}$ at $4^{\circ} \mathrm{C}$ to obtain a pellet containing brain capillary crude membranes. Crude membranes were resuspended in buffer and stored at $-80^{\circ} \mathrm{C}$.

\section{Western blotting}

Protein expression levels were determined by Western blot analysis as described in previous studies [9, 22]. Protein concentrations of brain capillary crude membrane samples and brain lysate samples were determined with the Bradford assay. The Invitrogen NuPage ${ }^{\circledR}$ Bis-Tris electrophoresis and blotting system was used to perform all Western blots. Following protein transfer, blotting membranes were blocked and incubated overnight with the primary antibody (P-gp: C219, $1 \mu \mathrm{g} / \mathrm{ml}$; hA $\beta 40$ : $1 \mu \mathrm{g} / \mathrm{ml}$; hA $\beta 42: 1 \mu \mathrm{g} / \mathrm{ml} ; \beta$-Actin: $1 \mu \mathrm{g} / \mathrm{ml})$. Blotting membranes were washed and incubated for 1 hour with horseradish peroxidase-conjugated ImmunoPure secondary IgG antibody $(1: 5000,0.15 \mu \mathrm{g} / \mathrm{ml}$; Thermo Fisher Scientific, Waltham, MA, USA). Proteins were detected using SuperSignal West Pico Chemiluminescent Substrate (Thermo Fisher Scientific, Waltham, MA, USA). Protein bands were visualized using a Bio-Rad ChemiDoc XRS + gel documentation system. Optical density and digital molecular weight analyses were performed using Image Lab 5.0 software from Bio-Rad Laboratories (RRID:SCR_014210) and a molecular weight marker (RPN800E; GE Healthcare, Chalfont St. Giles, Buckinghamshire, UK). Linear adjustments of contrast and brightness were applied to entire Western blot images. Nonlinear adjustments were not applied.

\section{P-gp transport activity and p-gp-mediated $h A \beta 42$ transport}

$\mathrm{P}$-gp transport activity levels and P-gp-mediated $\mathrm{A} \beta$ transport were determined as previously described [ 9 , 28 , 29]. To determine P-gp transport activity, freshly isolated brain capillaries were incubated with $2 \mu \mathrm{M}$ of the P-gp-specific substrate NBD-cyclosporin A (NBD-CSA) in DPBS for 1 hour. To assess P-gp-mediated hA $\beta 42$ transport activity, brain capillaries were incubated with 5 $\mu \mathrm{M}$ fluorescein-hA $\beta 42$ in DPBS for 1 hour. Images of 10 capillaries per treatment group were captured by confocal microscopy using the $488 \mathrm{~nm}$ line of an argon laser of a Leica TCS SP5 confocal microscope with a $63 \times 1.2$ NA water immersion objective (Leica Instruments, Wetzlar, Germany). NBD-CSA fluorescence in the capillary lumen was measured in each image using Image $J$ v.1.48v (Wayne Rasband, NIH, USA; RRID:SCR_003070). Specific, luminal NBD-CSA or fluorescein-hA $\beta 42$ fluorescence were measured as the difference between total luminal fluorescence and fluorescence in the presence of $5 \mu \mathrm{M}$ PSC833, a P-gp-specific inhibitor $[9,28,29]$.

\section{$A \beta$ immunostaining of brain capillaries}

Freshly isolated brain capillaries were immunostained for $\mathrm{hA} \beta 40$ and $\mathrm{hA} \beta 42$ using a method described in previous studies [9]. Mouse brain capillaries were fixed with $3 \%$ paraformaldehyde $/ 0.25 \%$ glutaraldehyde for $30 \mathrm{~min}$ at room temperature and subsequently washed with PBS. Fixed capillaries were treated with $0.5 \%$ Triton X-100 for 30 min, washed with PBS and blocked with $1 \%$ BSA/DPBS for $60 \mathrm{~min}$. Capillaries were incubated overnight using a 1:250 dilution $(4 \mu \mathrm{g} / \mathrm{ml})$ of primary rabbit polyclonal antibody to human A $\beta 1-40$ (hA 340 ; ab12265, Abcam, Cambridge, MA, USA; RRID:AB_298985) or primary rabbit polyclonal antibody to human $A \beta 1$ 42 (hAß42; ab12267, Abcam, Cambridge, MA, USA; RRID:AB_298987). Capillaries were washed with $1 \%$ $\mathrm{BSA} / \mathrm{PBS}$ for $60 \mathrm{~min}$ and incubated with secondary Alexa-Fluor 488-conjugated goat anti-rabbit IgG (1:1000, $1 \mu \mathrm{g} / \mathrm{ml}$; Invitrogen, Carlsbad, CA, USA; RRID:AB 2,576,217) for $1 \mathrm{~h}$ at $37^{\circ} \mathrm{C}$. Nuclei were counterstained with $1 \mu \mathrm{g} / \mathrm{ml}$ DAPI (MilliporeSigma, Burlington, MA USA;RRID:SCR_014366). Immunofluorescence of hA $\beta 40$ and hA $\beta 42$ was visualized by confocal microscopy (Leica TCS SP 5 confocal microscope, $62 \times 1.2 \mathrm{NA}$ water objective, Leica Instruments, Weltzar, Germany). Brain capillary plasma membrane immunofluorescence of hA $\beta 40$ and hA $\beta 42$ was measured for each capillary with ImageJ software v1.48 as previously described $[9,23]$. A $10 \times 10$ grid was superimposed on each image and fluorescence measurements of capillary membranes were taken between intersecting grid lines. The fluorescence intensity for each capillary was the mean of three measurements per capillary.

\section{hA $\beta 40$ and $h A \beta 42$ ELISA}

Human $A \beta 40$ and $A \beta 42$ levels in plasma and brain samples were determined by ELISA following the manufacturer's protocols (KHB3482 (sensitivity: $<6 \mathrm{pg} / \mathrm{ml}$ ) and KHB3442 (sensitivity: < $10 \mathrm{pg} / \mathrm{ml}$ ); Invitrogen, Camarillo, CA, USA). Plasma samples were centrifuged at $5000 \mathrm{~g}$ for $5 \mathrm{~min}$ at $4{ }^{\circ} \mathrm{C}$, and then diluted with standard diluent buffer provided in the kit (hA $\beta 40$ : 1:50 dilution; hAß42: 1:4 dilution). Brain samples were homogenized in guanidine Tris- $\mathrm{HCl}$ buffer $(5 \mathrm{M}, \mathrm{pH} 8)$ and diluted in DPBS containing 5\% BSA and 0.03\% Tween-20 (hA 340 : 1:20 dilution; hA $\beta 42:$ 1:5 dilution). Diluted samples were centrifuged at $16,000 \mathrm{~g}$ for $20 \mathrm{~min}$ at $4{ }^{\circ} \mathrm{C}$; the supernatant was analyzed by ELISA. Absorbance $(450 \mathrm{~nm})$ was measured using a Synergy ${ }^{\mathrm{TM}}$ H1 Hybrid Multi-Mode Reader (BioTek, Winooski, VT, USA). A standard curve 
was plotted using Gen $5^{\mathrm{TM}}$ software v2.07 to determine the concentration of $\mathrm{hA} \beta 40$ and $\mathrm{hA} \beta 42$ in plasma and brain samples; values obtained at $450 \mathrm{~nm}$ were corrected for background absorbance; four parameter logistic ELISA curve fitting was used.

\section{Results}

We previously reported that hA $\beta 40$ triggers degradation of P-gp at the blood-brain barrier [22, 23]. We found that hA $\beta 40$ activates the ubiquitin-proteasome system, which leads to internalization and proteasomal degradation of the transporter $[22,24]$. Further, we showed that inhibition of intracellular trafficking with microtubule inhibitors blocks proteasomal degradation of P-gp in isolated brain capillaries [22]. The present study extends these findings to an in vivo strategy designed to protect P-gp from degradation by blocking transporter internalization.

\section{Effect of NCZ on P-gp protein expression and transport activity}

Microtubule inhibitors, such as nocodazole, have been shown to disrupt intracellular trafficking and internalization of membrane proteins, such as P-gp [22, 30]. In the present study, we used transgenic hAPP mice (Tg2576 model), one of the best characterized AD models that overexpresses human APP which leads to A $\beta$ brain deposits [31]. At 8-weeks of age, hAPP mice have accumulation of human $A \beta$ in the brain and show reduced P-gp protein expression and transport activity at the blood-brain barrier $[9,23]$. We dosed 8-week old hAPP mice $(n=15)$ with the microtubule inhibitor nocodazole (NCZ; $5 \mathrm{mg} / \mathrm{kg}$, i.p.) once every three days for two weeks (Table 1). A second group of hAPP mice received $\mathrm{NCZ}$ once every three days and on the two days between NCZ injections, this group of mice also received the P-gp inhibitor cyclosporin A (CSA; $25 \mathrm{mg} / \mathrm{kg}$, p.o.; $\mathrm{n}=15)$. Note that the group of NCZ-CSA-treated hAPP mice served as a control for P-gp transport activity to account for NCZ-treatment effects that depend on P-gp transport activity. Wild Type (WT; $\mathrm{n}=10$ ) mice and hAPP control mice $(n=15)$ received vehicle.

We found that after 14 days of treatment, P-gp protein expression levels in brain capillary membranes from NCZ-treated hAPP mice were comparable to those observed in WT mice (Fig. 1a). The same effect was observed in NCZ-CSA-treated mice. In contrast, vehicle-treated hAPP mice showed significantly decreased P-gp protein expression levels. Western blots were quantified by optical density analysis and normalized to $\beta$-actin (Table 2). Optical density measurements of P-gp protein expression levels $(n=3$, normalized to $\beta$-actin, SEM, $p$-value) are reported as percentage relative to WT control mice: hAPP: $51 \pm 3 \%(\Delta=-49 \% ; p=0.0093$;

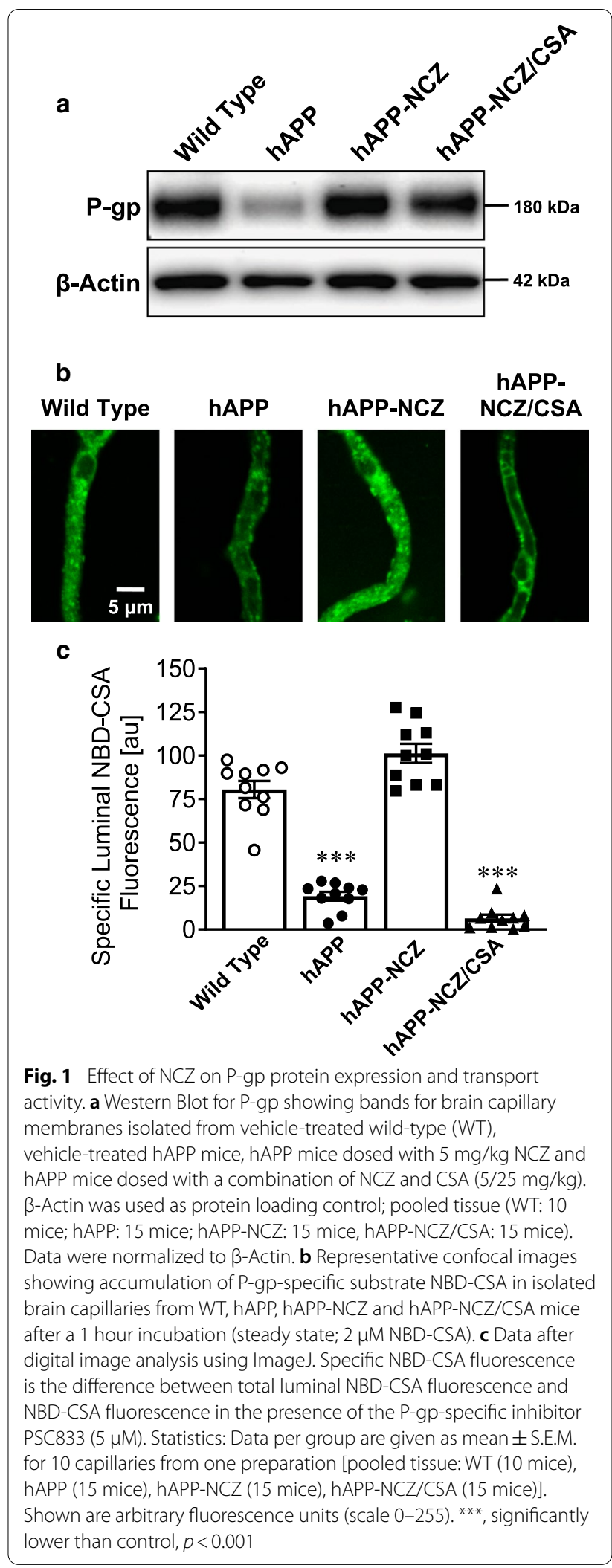


Table 2 Western blot analysis of P-gp protein expression levels in brain capillaries isolated from WT and hAPP mice (Fig. 1a)

\begin{tabular}{lllll}
\hline Protein & Wild Type & hAPP & hAPP-NCZ & hAPP-NCZ/CSA \\
\hline P-gp & $100 \pm 13$ & $51 \pm 3^{*}$ & $102 \pm 7$ & $91 \pm 6$
\end{tabular}

Data were obtained from optical density measurements and were normalized to $\beta$-actin levels; values are given as \%control $\pm \operatorname{SEM}(n=3)$

*Indicates statistical significance determined at the 0.05 level for each endpoint compared to control using Dunnett's many-to-one $t$-test

Tukey's HSD post hoc test); hAPP-NCZ: $102 \pm 7 \%$ ( $\Delta=2 \% ; p=1.00$; Tukey's HSD post hoc test), and hAPPNCZ/CSA: $91 \pm 6 \%$ ( $\Delta=-9 \% ; p=0.83$; Tukey's HSD post hoc test).

We also determined P-gp transport activity levels by live-cell imaging of isolated brain capillaries according to a previously established protocol $[9,22,25,28]$. Briefly, freshly isolated brain capillaries are transferred onto a glass cover slip and incubated for 1 hour with the fluorescent P-gp substrate NBD-cyclosporin A (NBD-CSA, $2 \mu \mathrm{M})$. Brain capillaries are then imaged using confocal microscopy and fluorescence of NBD-CSA accumulation in the capillary lumen is measured by quantitative image analysis using ImageJ. Changes in luminal NBD-CSA fluorescence compared to WT control indicate changes in P-gp transport activity. Thus, luminal NBD-CSA fluorescence is an indirect measure of $\mathrm{P}$-gp transport activity. Figure $1 \mathrm{~b}$ shows representative confocal images of brain capillaries isolated from WT mice, hAPP mice, NCZ-treated hAPP mice, and hAPP mice treated with the combination of NCZ-CSA after a one-hour exposure to $2 \mu \mathrm{M}$ NBD-CSA. Image analysis shows that specific luminal NBD-CSA fluorescence levels in the lumens of brain capillaries from hAPP mice were decreased by $76 \%$ ( $p<0.0001$; Tukey's HSD post hoc test) compared to levels in capillaries from WT mice (Fig. 1c). Luminal NBD-CSA fluorescence levels in brain capillaries from NCZ-treated hAPP mice were increased by $26 \%$ relative to levels measured in capillaries from WT mice $(p=0.03$; Tukey's HSD post hoc test). Compared to WT mice, luminal NBDCSA fluorescence levels in brain capillaries from NCZtreated hAPP mice that received CSA were reduced by $92 \%$. This decrease in luminal NBC-CSA fluorescence is comparable to that found in vehicle-treated hAPP mice $(p<0.0001$; Tukey's HSD post hoc test). Thus, we found decreased luminal NBD-CSA fluorescence in brain capillaries isolated from untreated hAPP mice and NCZCSA-treated hAPP mice, whereas luminal NBD-CSA fluorescence levels in brain capillaries from NCZ-treated hAPP mice were similar to those observed in capillaries from WT mice. Note that we previously published a control experiment showing that nocodazole alone has no effect on P-gp protein expression and transport activity in isolated brain capillaries [22]. Thus, it is unlikely that the observed effects are due to nocodazole-mediated induction of P-gp protein expression.

In summary, the findings described in Fig. 1 show that treating hAPP mice with NCZ for two weeks restored P-gp protein expression and transport activity levels in brain capillaries. The data presented here together with our previously published work suggest that NCZ likely prevents P-gp internalization and degradation $[22,23]$.

\section{Effect of NCZ on p-gp-mediated A $\beta$ transport in hAPP mice} Next, we assessed P-gp-mediated transport of fluorescent labeled hA $\beta 42$ in isolated brain capillaries from mice in all four treatment groups. In these experiments, isolated brain capillaries were incubated to steady state with fluorescein-hA $\beta 42$ (FL-hA $\beta 42 ; 5 \mu \mathrm{M})$ for 1 hour before we imaged the capillaries with a confocal microscope. FL-hA $\beta 42$ fluorescence in capillary lumens was analyzed by quantitative image analysis [9, 22, 25, 28]. Figure 2a shows representative confocal images of isolated brain capillaries incubated to steady state with $5 \mu \mathrm{M}$ FL-hA 342 . These images show reduced luminal FL-hA 342 fluorescence in capillaries from vehicle-treated hAPP mice and in hAPP mice treated with NCZ-CSA compared to WT and NCZ-treated hAPP mice. Note that CSA is a competitive P-gp inhibitor, and therefore, $\mathrm{P}$-gp-mediated FL-hA $\beta 42$ transport is reduced in isolated capillaries from hAPP mice that received the combination NCZ-CSA. Image analysis shows that in capillaries from hAPP mice, luminal FL-hA 342 fluorescence was decreased by $68 \%$ ( $p=0.0023$; Tukey's HSD post hoc test) compared to capillaries from WT mice (Fig. 2b). In brain capillaries from NCZ-CSA-treated hAPP mice, luminal FL-hA 342 fluorescence is significantly decreased by $68 \%$ ( $p=0.0007$; Tukey's HSD post hoc test) compared to that in capillaries from WT control mice. In contrast, luminal FL-hA 342 fluorescence in capillaries from NCZ-treated hAPP mice was comparable to levels found in WT control mice $(\Delta=27 \% ; p=0.27$; Tukey's HSD post hoc test).

Together, the data in Figs. 1 and 2 suggest that treatment of hAPP mice with NCZ protects P-gp protein expression and transport activity at the blood-brain barrier.

\section{Effect of NCZ treatment on ALT levels}

During the two-week treatment with NCZ, animals were continuously monitored by daily health checks, and we observed no NCZ-induced visible adverse effects. We also determined alanine-aminotransferase (ALT) activity levels in liver tissue samples from treated and untreated animals after the 2-week dosing period to determine potential NCZ-induced liver 


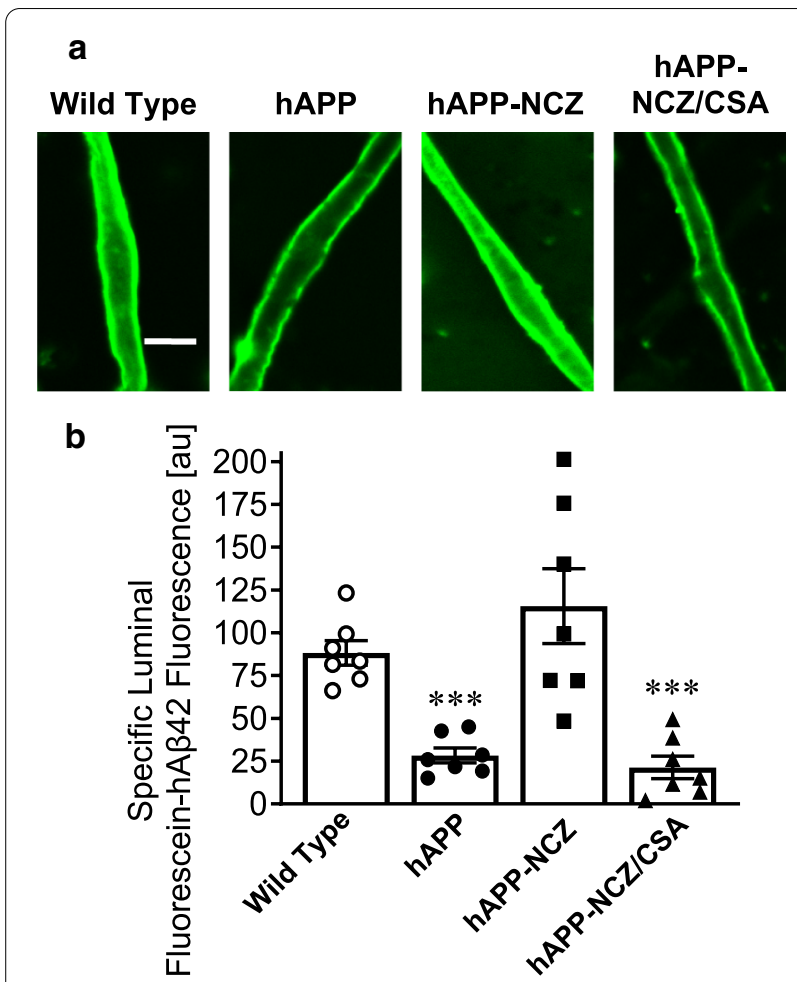

Fig. 2 Effect of NCZ on P-gp-Mediated hAß42 transport. a Representative confocal images of isolated brain capillaries showing accumulation of fluorescein-hA 342 in capillary lumens after a 1 hour incubation (steady state; $5 \mu \mathrm{M}$ fluorescein-hAß42). b Data after digital image analysis using ImageJ. Specific fluorescein-hAß42 fluorescence is the difference between total luminal fluorescein-hAß42 fluorescence and fluorescein-hAß42 fluorescence in the presence of the P-gp-specific inhibitor PSC833 (5 $\mu$ M). Statistics: Data per group are given as mean \pm S.E.M. for 10 capillaries from one preparation (pooled tissue: WT (10 mice), hAPP (15 mice), hAPP-NCZ (15 mice), hAPP-NCZ/CSA (15 mice)). Shown are arbitrary fluorescence units (scale 0-255). ${ }^{* * *}$, significantly lower than control, $p<0.001$ toxicity. Increased ALT activity levels can be an indicator of liver damage and toxicity and are generally used in the clinic to monitor overall health, in particular to detect drug-induced liver toxicity [32]. ALT activity levels from all treatment groups ranged between 2,599 and $2,881 \mathrm{mU} / \mathrm{ml}$; there was no significant difference between any of the groups $\left(\mathrm{F}_{3,51}=1.1, p=0.36\right.$; ANOVA; Fig. 3).

These data show that the 2-week NCZ treatment did not affect ALT activity, which suggests that NCZ did not induce liver damage in the animals during the treatment phase. More studies are necessary to fully evaluate the safety of $\mathrm{NCZ}$, especially with regard to a long-term treatment regimen.

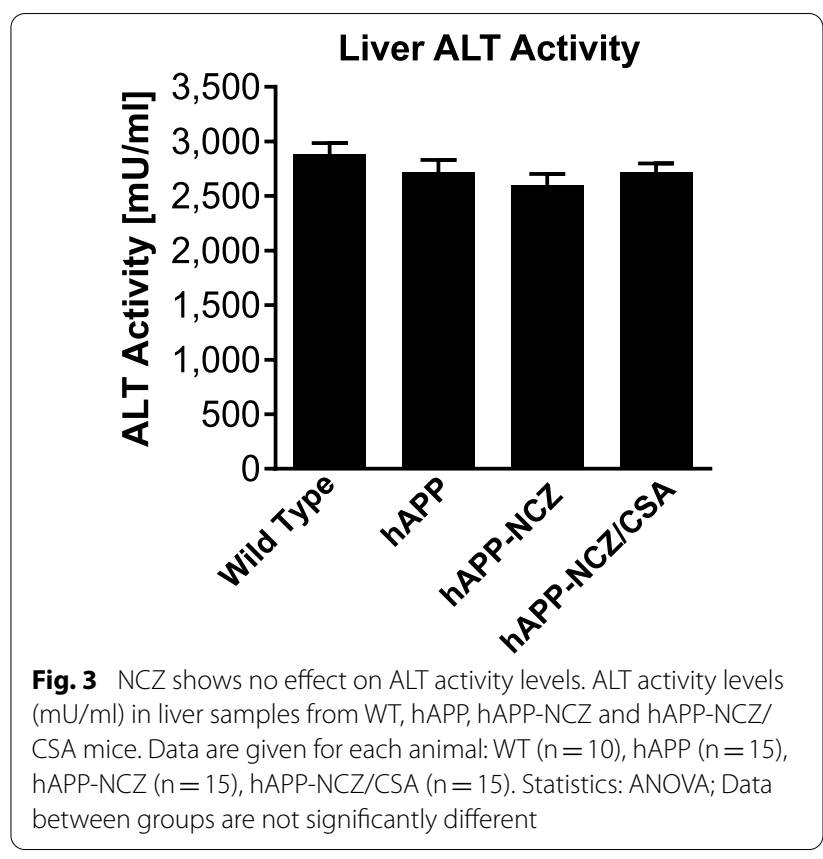

Effect of NCZ treatment on A $\beta$ levels in hAPP mice

Next we evaluated the effect of NCZ treatment on hA $\beta 40$ and hA $\beta 42$ levels in plasma, brain capillary membranes, and brain tissue.

We used ELISA to determine plasma $\mathrm{hA} \beta 40$ and $\mathrm{hA} \beta 42$ protein levels (Fig. 4a, b). hA $\beta 40$ levels were in the range 3,656-3,797 $\mathrm{pg} / \mathrm{ml}$ with no significant difference between groups $\left(\mathrm{F}_{2,42}, p=0.98\right.$; ANOVA). For $\mathrm{hA} \beta 42$, we found levels ranging from 200 to $244 \mathrm{pg} / \mathrm{ml}$, also with no significant difference between groups $\left(\mathrm{F}_{2,42}=0.13, p=0.88\right.$; ANOVA). This finding is consistent with rapid $A \beta$ clearance from blood by the liver and the kidney [33]. Note that samples from WT mice were not included in the analysis since WT mice do not express human $A \beta$.

One characteristic of $A D$ is accumulation of $A \beta$ in blood vessel walls [27, 34]. We therefore determined capillary-associated hA $\beta$ levels with immunohistochemistry. Freshly isolated brain capillaries were immunostained for hA $\beta 40$ and hA $\beta 42$, imaged with a confocal microscope, followed by image analysis of capillary membranes. Brain capillaries isolated from treated and untreated hAPP mice stained positive for both hA $\beta 40$ and hA $\beta 42$ (Fig. $5 \mathrm{a}$, b). Image analysis revealed that NCZ-treatment lowered capillary-associated hA $\beta 40$ by $37 \%(p=0.0004$; Tukey's HSD post hoc test) compared to capillaries from vehicletreated hAPP mice. For hA $\beta 42$, no difference was found between treatment groups $(p=0.91$; Tukey's HSD post hoc test).

Finally, we analyzed hA $\beta 40$ and hA $\beta 42$ brain levels by Western blotting and ELISA. Western blotting showed reduced $h A \beta 40$ and $h A \beta 42$ protein levels in brain tissue 

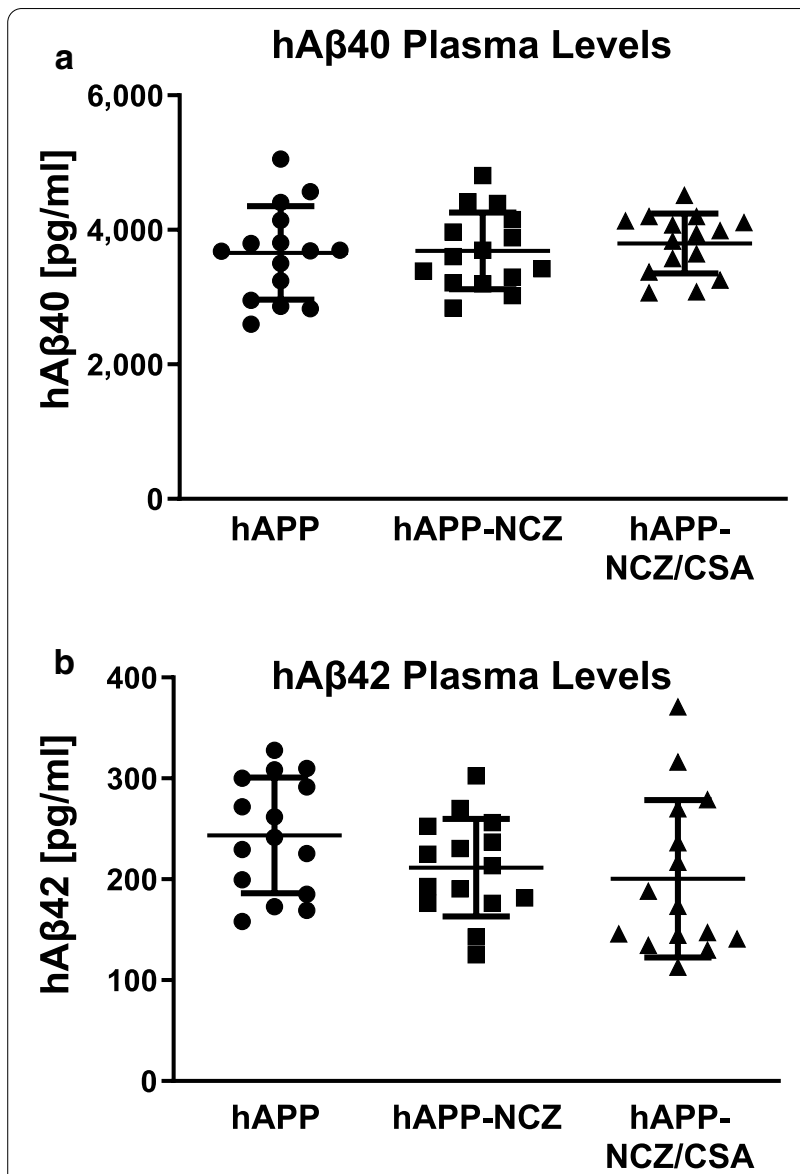

Fig. 4 NCZ treatment has no effect on $h A \beta 40$ and $h A \beta 42$ plasma levels in hAPP mice. a hAß40 levels (pg/ml) and b hAß42 levels (pg/ $\mathrm{ml}$ ) in plasma samples from WT, hAPP, hAPP-NCZ and hAPP-NCZ/ CSA mice. Data are given for each animal: WT $(n=10), \operatorname{hAPP}(n=15)$, hAPP-NCZ $(n=15)$, hAPP-NCZ/CSA $(n=15)$. Statistics: ANOVA; Data between groups are not significantly different

samples from NCZ-treated hAPP mice compared to untreated hAPP mice (Fig. 6a). In contrast, hA $\beta$ protein levels in brain tissue from NCZ-treated mice that also received CSA to control for P-gp transport activity appeared similar to those detected in brain tissue from vehicle-treated hAPP mice. Using ELISA, we found that in NCZ-treated hAPP mice hA $\beta 40$ brain levels were reduced by $48 \%(p<0.0001$; Tukey's HSD post hoc test) and hA $\beta 42$ brain levels were reduced by $30 \%$ ( $p=0.0008$; Tukey's HSD post hoc test) compared to vehicle-treated hAPP mice (Fig. 6b, c).

In summary, our data presented here together with our previously publish work support our proposed mechanism that blocking P-gp internalization with NCZ protects P-gp from proteasomal degradation, which helps reduce $A \beta$ brain load in hAPP mice (Fig. 7).

\section{Discussion}

We previously showed that $\mathrm{hA} \beta 40$ triggers (1) ubiquitination, (2) internalization, and (3) proteasomal degradation of blood-brain barrier P-gp, which results in decreased P-gp protein expression and transport function [22, 24]. We further demonstrated that preventing P-gp ubiquitination preserves P-gp protein expression and transport activity at the blood-brain barrier, which resulted in lower $A \beta$ brain levels in vivo [23]. Our present study builds on this existing work and extends these findings by targeting A $\beta$-driven P-gp internalization in vivo.

For the present study, we treated hAPP mice with the microtubule inhibitor, nocodazole (NCZ), and evaluated the effects of NCZ on P-gp protein expression and transport activity and $\mathrm{hA} \beta$ burden. We found that isolated brain capillaries from hAPP mice treated with NCZ had P-gp expression and transport activity levels comparable to those from WT control mice (Figs. 1 and 2). No adverse effects were noticed during nocodazole treatment, accordingly, ALT activity levels in liver samples were similar across all groups. The absence of adverse effects is likely due to the relatively short treatment phase of 2 weeks. (Fig. 3). No difference in hA $\beta 40$ and hA $\beta 42$ levels was detected in plasma samples from treated and un-treated hAPP mice (Fig. 4). We found that NCZ treatment decreased membrane-associated hA $\beta 40$ levels in hAPP mice (Fig. 5) and show that hA $\beta 40$ and hA $\beta 42$ levels were significantly lower in brain samples from NCZtreated hAPP mice compared to those in untreated hAPP mice and hAPP-NCZ/CSA control mice (Fig. 6). Based on these data we conclude that NCZ treatment protects $\mathrm{P}$-gp protein expression and transport activity levels at the blood-brain barrier and results in reduced $A \beta$ levels (Fig. 7). This effect is likely due to the inhibition of P-gp internalization and degradation by NCZ. In the following sections we discuss our findings in the context of the existing literature.

One mechanism that accounts for changes in P-gpmediated transport is trafficking between vesicular compartments and the plasma membrane. Arias and colleagues were the first to report membrane trafficking of several ABC transporters, including P-gp, bile salt export pump (BSEP), and Mrp2 at the bile canalicular membrane of hepatocytes [35,36]. These authors showed cycling of P-gp between intracellular pools and the plasma membrane by demonstrating insertion of P-gp into the canalicular membrane in response to cyclic AMP (cAMP) and taurocholate. This effect was independent from protein biosynthesis. In addition, the microtubule disruptor, colchicine, and the PI3 kinase inhibitor, wortmannin, inhibited membrane insertion of P-gp. On the other hand, it was also demonstrated that cholestasis caused retrieval of P-gp from the canalicular membrane into intracellular 


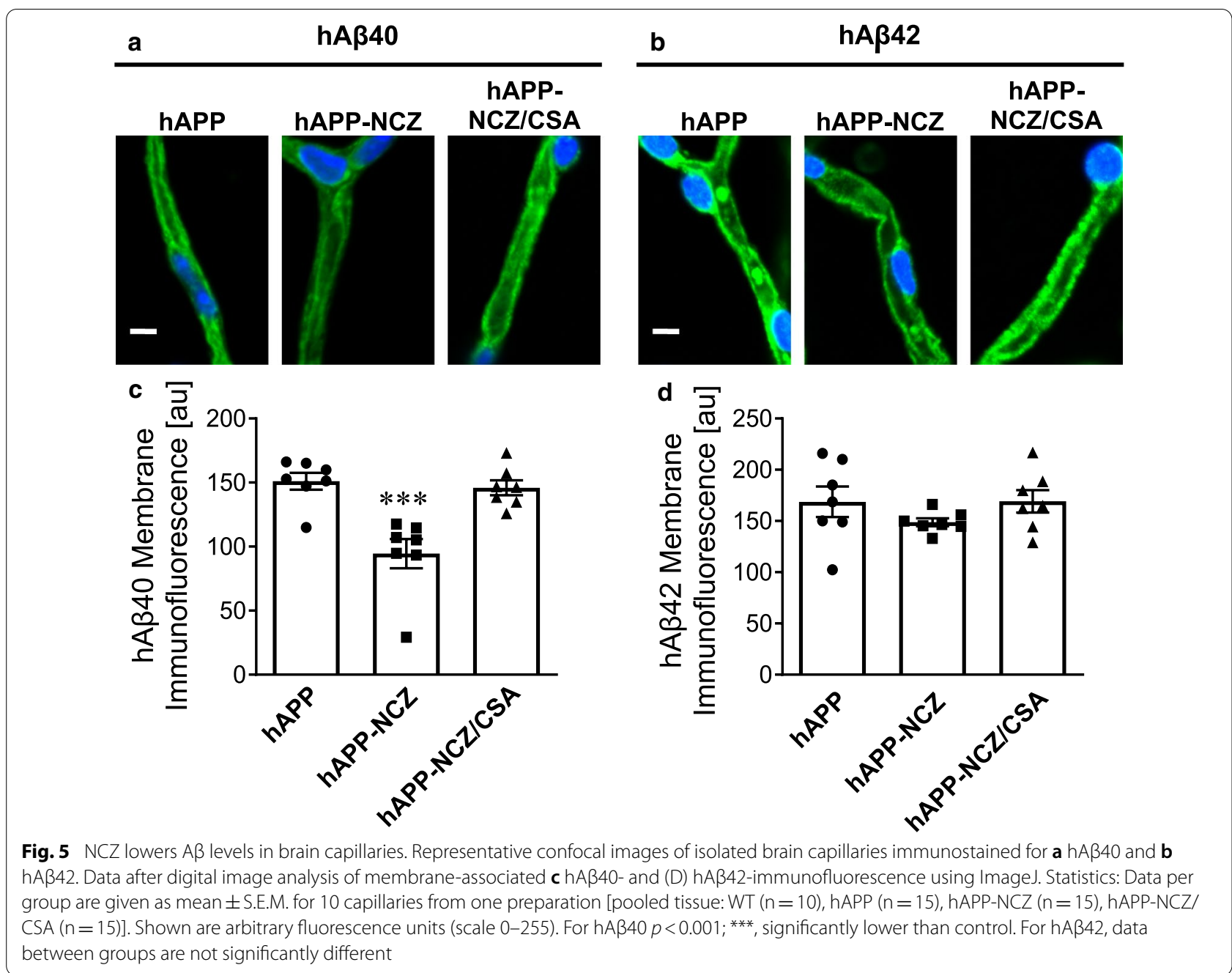

vesicles [35, 37, 38]. Sai et al. visualized P-gp trafficking between the pericanalicular region and the bile canalicular membrane in a hepatic cell line expressing GFPtagged P-gp [36]. These researchers also demonstrated an involvement of microtubules in P-gp membrane trafficking. Their results show that in hepatocytes, vesicular trafficking of P-gp depends on microtubules and modulates transport activity at the canalicular membrane. Recent studies indicate that P-gp trafficking is also an important mechanism to regulate P-gp transport activity at the blood-brain barrier. Hawkins and colleagues found that the vascular endothelial growth factor (VEGF) triggers removal of $\mathrm{P}$-gp from the luminal membrane resulting in decreased P-gp transport activity in brain capillaries [39]. This study provided first evidence that loss of P-gp transport activity can be due to P-gp internalization shifting the transporter into an intracellular compartment where it no longer functions as an efflux transporter. The effect of VEGF was blocked by nocodazole, whereas proteasome inhibition had no effect. In a series of elegant studies, McCaffrey, Tome and colleagues discovered that peripheral inflammatory pain leads to caveolin1-mediated trafficking of P-gp at the blood-brain barrier [40-42]. Caveolin-1 is a scaffolding protein that has been shown to interact with P-gp [43]. In the case of peripheral pain, P-gp levels increased at the luminal membrane of the brain capillary endothelium. In an in vitro study, Noack et al. found that drugs such as mitomycin $\mathrm{C}$ trigger P-gp trafficking in the hCMEC/D3 cell line [44]. Redistribution of P-gp from intracellular pools to the cell membrane occurred within 2 hours of incubation with mitomycin C. Little is known about signaling steps through which P-gp internalization and/or trafficking of the transporter to the membrane occurs at the bloodbrain barrier. Work in liver and cancer cells showed that Src kinase interacts with P-gp and that this interaction is likely responsible for P-gp membrane localization [45]. Several studies found that Pim-1 kinase phosphorylates 

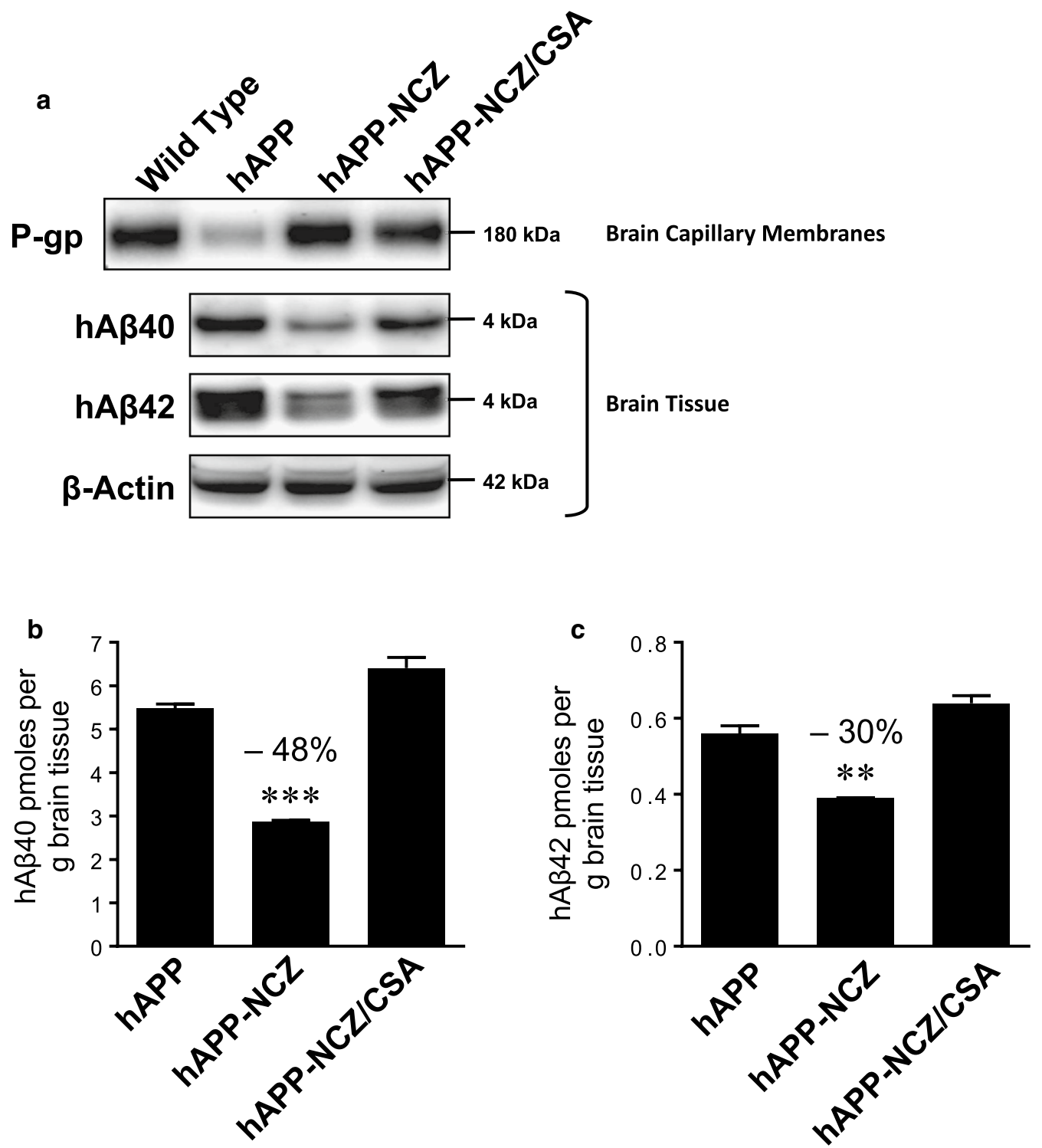

Fig. 6 NCZ lowers $A \beta$ brain levels. a Western Blot showing $h A \beta 40$ and $h A \beta 42$ protein expression levels in brain tissue samples from vehicle-treated WT, vehicle-treated hAPP mice, hAPP mice dosed with $5 \mathrm{mg} / \mathrm{kg} \mathrm{NCZ}$ and hAPP mice dosed with a combination of NCZ and CSA (5/25 mg/kg). $\beta$-Actin was used as protein loading control. b hAB40 and $\mathbf{c}$ hAß42 levels $(\mathrm{pg} / \mathrm{ml})$ in brain tissue samples from hAPP, hAPP-NCZ and hAPP-NCZ/CSA mice determined by ELISA. Statistics: ${ }^{* *}$, significantly lower than control, $p<0.001$; ${ }^{*}$, significantly lower than control, $p<0.01$

P-gp, which seems to be necessary for plasma membrane localization of the transporter [46-49]. However, the role Pim-1 plays in P-gp internalization and trafficking still needs to be determined in more detail. We recently observed that nanomolar concentrations of hA $\beta 40$ trigger P-gp degradation through the ubiquitin-proteasome system [22, 24]. Inhibiting protein ubiquitination, protein trafficking, and the proteasome prevented hA $\beta 40$ mediated decrease of $\mathrm{P}$-gp protein expression and transport activity. In a subsequent study we showed that inhibiting the ubiquitin-activating enzyme E1 with
PYR41 prevented P-gp ubiquitination in vivo prevented P-gp degradation and lowered $A \beta$ brain levels [23]. The present study expands this work by treating hAPP mice with the microtubule inhibitor nocodazole in vivo and demonstrates that P-gp expression and activity can be protected with NCZ. In both studies, we used prefrontal cortex for $A \beta$ quantification since this brain region is highly affected in $A D$ and shows early signs of $A \beta$ deposition, while the remaining part of the cerebral cortex was used to isolate brain capillaries. Comparing the data from our previous study with PYR41 and the data from the 


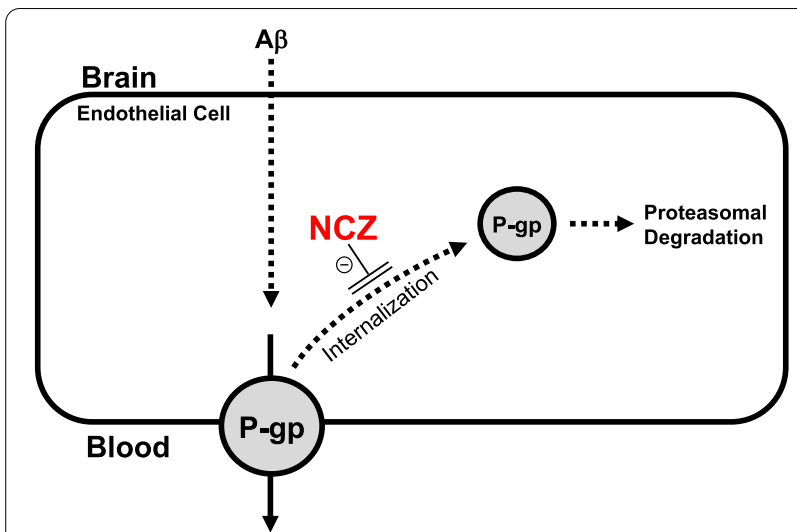

Fig. 7 Proposed mechanism. Based on our data presented here and our previously published data [22,23], we propose that blocking A $\beta$-induced internalization protects P-gp from proteasomal degradation, which preserves P-gp protein expression and transport activity and helps to reduce A $\beta$ brain levels in hAPP mice

present study with nocodazole, we found no difference between the effects of PYR41 and nocodazole on protecting P-gp from degradation and decreasing $A \beta$ brain levels (A 340 : NCZ 48\% vs. PYR41 53\% and A 342 : NCZ 30\% vs. PYR41 33\%).

Drug combinations are often applied to treat complex diseases and synergistic effects among different drugs hold the promise to achieve larger effects with lower doses and reduced side effect profiles [50]. Drugs acting on the same signaling pathway by targeting different signaling molecules are more likely to produce synergistic effects. Thus, based on our proposed signaling pathway (Fig. 7), inhibiting both ubiquitination and internalization at the same time has the potential for synergistic effects on preserving P-gp and lowering $A \beta$ brain levels. Clearly, future studies are needed to demonstrate such potentially synergistic effects.

\section{Conclusions}

Based on our previously published work and the data presented here, we conclude that inhibiting P-gp internalization with a microtubule inhibitor could be used to protect P-gp from degradation which could help lower $\mathrm{A} \beta$ brain levels in $\mathrm{AD}[22,23]$. Therefore, modulating P-gp trafficking could be a potential new therapeutic target to help protect P-gp at the blood-brain barrier in AD. Currently, microtubule inhibitors are approved for solid and hematologic cancers and include agents such as taxanes, vinca alkaloids, and epothilones. Several drugs including vincristine and colcemid are similar to nocodazole in that they interfere with microtubule polymerization [51]. Thus, there is the possibility of therapeutically targeting $\mathrm{P}$-gp trafficking in AD. However, neuronal activity depends to a large extent on vesicular trafficking, and thus, a microtubule inhibitor would be needed that is suitable and safe for the use in CNS disorders including AD. Clearly, more work is needed to evaluate the potential therapeutic benefit of blocking P-gp internalization in $\mathrm{AD}$.

\section{Acknowledgements \\ We thank the members of the Hartz and Bauer laboratories for proofreading the manuscript.}

\section{Authors' contributions}

AMSH and BB contributed to the major design, acquisition, analysis and interpretation of data for the work and wrote and revised the manuscript. YD carried out ALT assay and wrote parts of the manuscript. YZ analyzed A $\beta$ brain and plasma levels. AB carried out the in vivo study and edited the manuscript. ELA provided all statistical analyses. All authors were involved in drafting and revising the work for important intellectual content. All authors approved the final version and agreed to be accountable for all aspects of the work in ensuring that questions related to the accuracy or integrity of any part of the work are appropriately investigated and resolved. All authors read and approved the final manuscript.

\section{Funding}

This project was supported by grant number 2R01AG039621 from the National Institute on Aging (to A.M.S.H.). The content is solely the responsibility of the authors and does not necessarily represent the official views of the National Institute on Aging or the National Institutes of Health.

\section{Availability of data and Materials}

The datasets used and/or analyzed during the current study are available from the corresponding author on reasonable request.

\section{Declarations}

Ethics approval and Consent to participate

Not applicable.

\section{Consent for publication}

Not applicable.

\section{Competing interests}

The authors declare that they have no competing interests.

\section{Author details}

1 Sanders-Brown Center on Aging, University of Kentucky, Lexington, KY 40536, USA. ${ }^{2}$ Department of Pharmacy Practice and Pharmaceutical Sciences, College of Pharmacy, University of Minnesota, Duluth, Minnesota 55812, USA. ${ }^{3}$ Department of Pharmacology and Nutritional Sciences, University of Kentucky, Lexington, KY 40536, USA. ${ }^{4}$ Department of Pharmaceutical Sciences, College of Pharmacy, University of Kentucky, Lexington, KY 40536, USA. ${ }^{5}$ Department of Epidemiology, College of Public Health, University of Kentucky, Lexington, KY 40536, USA. ${ }^{6}$ University of Kentucky Sanders-Brown Center on Aging, 800 S Limestone, Lexington, KY 40536, USA.

Received: 22 November 2020 Accepted: 25 February 2021 Published online: 06 March 2021

\section{References}

1. Gravina SA, Ho L, Eckman CB, Long KE, Otvos L Jr, Younkin LH, et al. Amyloid beta protein (A beta) in Alzheimer's disease brain. Biochemical and immunocytochemical analysis with antibodies specific for forms ending at A beta 40 or A beta 42(43). J Biol Chem. 1995;270(13):7013-6.

2. Hardy J, Selkoe DJ. The amyloid hypothesis of Alzheimer's disease: progress and problems on the road to therapeutics. Science. 2002;297(5580):353-6. 
3. Shibata M, Yamada S, Kumar SR, Calero M, Bading J, Frangione B, et al. Clearance of Alzheimer's amyloid-ss(1-40) peptide from brain by LDL receptor-related protein-1 at the blood-brain barrier. J Clin Invest. 2000;106(12):1489-99.

4. Frangione Zlokovic B. Transport-clearance hypothesis for Alzheimer's disease and potential therapeutic implications. Landes Biosci. 2003;54:114-22.

5. Zlokovic BV, Deane R, Sallstrom J, Chow N, Miano JM. Neurovascular pathways and Alzheimer amyloid beta-peptide. Brain Pathol. 2005;15(1):78-83.

6. Bruckmann S, Brenn A, Grube M, Niedrig K, Holtfreter S, von B und Halbach. O, et al. Lack of P-glycoprotein Results in Impairment of Removal of Beta-Amyloid and Increased Intraparenchymal Cerebral Amyloid Angiopathy after Active Immunization in a Transgenic Mouse Model of Alzheimer's Disease. Curr Alzheimer Res. 2017;14(6):656-67.

7. Callaghan R, Gelissen IC, George AM, Hartz AMS. Mamma Mia, P-glycoprotein binds again. FEBS Lett. 2020;87:25.

8. Cirrito JR, Deane R, Fagan AM, Spinner ML, Parsadanian M, Finn MB, et al. P-glycoprotein deficiency at the blood-brain barrier increases amyloidbeta deposition in an Alzheimer disease mouse model. J Clin Invest. 2005;115(11):3285-90.

9. Hartz AM, Miller DS, Bauer B. Restoring blood-brain barrier P-glycoprotein reduces brain amyloid-beta in a mouse model of Alzheimer's disease. Mo Pharmacol. 2010;77(5):715-23.

10. Kuhnke D, Jedlitschky G, Grube M, Krohn M, Jucker M, Mosyagin I, et al. MDR1-P-Glycoprotein (ABCB1) Mediates Transport of Alzheimer's amyloid-beta peptides-implications for the mechanisms of Abeta clearance at the blood-brain barrier. Brain Pathol. 2007;17(4):347-53.

11. Lam FC, Liu R, Lu P, Shapiro AB, Renoir JM, Sharom FJ, et al. beta-Amyloid efflux mediated by p-glycoprotein. J Neurochem. 2001;76(4):1121-8.

12. McCormick JA, Chen L, Vogel G, Wise PDJG. Transport of Alzheimer's Associated Amyloid-beta Catalyzed by P-glycoprotein. bioRxiv. 2020;4:78.

13. Wang W, Bodles-Brakhop AM, Barger SW. A Role for P-Glycoprotein in Clearance of Alzheimer Amyloid beta -Peptide from the Brain. Curr Alzheimer Res. 2016;13(6):615-20.

14. Yuede CM, Lee H, Restivo JL, Davis TA, Hettinger JC, Wallace CE, et al, Rapid in vivo measurement of beta-amyloid reveals biphasic clearance kinetics in an Alzheimer's mouse model. J Exp Med. 2016;213(5):677-85.

15. Carrano A, Snkhchyan H, Kooij G, van der Pol S, van Horssen J, Veerhuis R, et al. ATP-binding cassette transporters P-glycoprotein and breast cancer related protein are reduced in capillary cerebral amyloid angiopathy. Neurobiol Aging. 2014;35(3):565-75.

16. Chiu C, Miller MC, Monahan R, Osgood DP, Stopa EG, Silverberg GD. P-glycoprotein expression and amyloid accumulation in human aging and Alzheimer's disease: preliminary observations. Neurobiol Aging. 2015;36(9):2475-82.

17. Jeynes B, Provias J. An investigation into the role of P-glycoprotein in Alzheimer's disease lesion pathogenesis. Neurosci Lett. 2011;487(3):389-93.

18. Wijesuriya HC, Bullock JY, Faull RL, Hladky SB, Barrand MA. ABC efflux transporters in brain vasculature of Alzheimer's subjects. Brain Res. 2010;1358:228-38.

19. Kannan P, Schain M, Kretzschmar WW, Weidner L, Mitsios N, Gulyas B, et al. An automated method measures variability in P-glycoprotein and ABCG2 densities across brain regions and brain matter. J Cereb Blood Flow Metab. 2017:37(6):2062-75.

20. Deo AK, Borson S, Link JM, Domino K, Eary JF, Ke B, et al. Activity of P-Glycoprotein, a beta-Amyloid Transporter at the Blood-Brain Barrier, Is Compromised in Patients with Mild Alzheimer Disease. J Nucl Med. 2014;55(7):1106-11.

21. van Assema DM, Lubberink M, Boellaard R, Schuit RC, Windhorst AD, Scheltens $\mathrm{P}$, et al. P-glycoprotein function at the blood-brain barrier: effects of age and gender. Mol Imaging Biol. 2012;14(6):771-6.

22. Hartz AM, Zhong Y, Wolf A, LeVine H 3rd, Miller DS, Bauer B. Abeta40 Reduces P-Glycoprotein at the Blood-Brain Barrier through the UbiquitinProteasome Pathway. J Neurosci. 2016;36(6):1930-41.

23. Hartz AMS, Zhong Y, Shen AN, Abner EL, Bauer B. Preventing P-gp Ubiquitination Lowers Abeta Brain Levels in an Alzheimer's Disease Mouse Model. Front Aging Neurosci. 2018;10:186.

24. Akkaya BG, Zolnerciks JK, Ritchie TK, Bauer B, Hartz AM, Sullivan JA, et al. The multidrug resistance pump $A B C B 1$ is a substrate for the ubiquitin ligase NEDD4-1. Mol Membr Biol. 2015;32(2):39-45.
25. Hartz AM, Pekcec A, Soldner EL, Zhong Y, Schlichtiger J, Bauer B. P-gp Protein Expression and Transport Activity in Rodent Seizure Models and Human Epilepsy. Mol Pharm. 2017;14(4):999-1011.

26. Wenger RM. Cyclosporine and analogues-isolation and synthesis-mechanism of action and structural requirements for pharmacological activity. Fortschr Chem Org Naturst. 1986;50:123-36.

27. Hartz AM, Bauer B, Soldner EL, Wolf A, Boy S, Backhaus R, et al. Amyloidbeta contributes to blood-brain barrier leakage in transgenic human amyloid precursor protein mice and in humans with cerebral amyloid angiopathy. Stroke. 2012;43(2):514-23.

28. Hartz AM, Bauer B, Block ML, Hong JS, Miller DS. Diesel exhaust particles induce oxidative stress, proinflammatory signaling, and P-glycoprotein up-regulation at the blood-brain barrier. FASEB J. 2008;22(8):2723-33.

29. Hartz AM, Bauer B, Fricker G, Miller DS. Rapid regulation of P-glycoprotein at the blood-brain barrier by endothelin-1. Mol Pharmacol. 2004;66(3):387-94.

30. Kim NH, Chung KS, Day BN. The distribution and requirements of microtubules and microfilaments during fertilization and parthenogenesis in pig oocytes. J Reprod Fertil. 1997;111(1):143-9.

31. Hsiao K, Chapman P, Nilsen S, Eckman C, Harigaya Y, Younkin S, et al. Correlative memory deficits, Abeta elevation, and amyloid plaques in transgenic mice. Science. 1996;274(5284):99-102.

32. Liu Z, Que S, Xu J, Peng T. Alanine aminotransferase-old biomarker and new concept: a review. Int J Med Sci. 2014;11(9):925-35.

33. Ghiso J, Shayo M, Calero M, Ng D, Tomidokoro Y, Gandy S, et al. Systemic catabolism of Alzheimer's Abeta40 and Abeta42. J Biol Chem. 2004:279(44):45897-908.

34. Love S, Miners S, Palmer J, Chalmers K, Kehoe P. Insights into the pathogenesis and pathogenicity of cerebral amyloid angiopathy. Front Biosci (Landmark Ed). 2009;14:4778-92.

35. Kipp H, Arias IM. Trafficking of canalicular ABC transporters in hepatocytes. Annu Rev Physiol. 2002;64:595-608.

36. Sai Y, Nies AT, Arias IM. Bile acid secretion and direct targeting of mdr 1green fluorescent protein from Golgi to the canalicular membrane in polarized WIF-B cells. J Cell Sci. 1999;112(Pt 24):4535-45.

37. Gatmaitan ZC, Nies AT, Arias IM. Regulation and translocation of ATP-dependent apical membrane proteins in rat liver. Am J Physiol. 1997:272(5 Pt 1):G1041-9.

38. Kipp H, Pichetshote N, Arias IM. Transporters on demand: intrahepatic pools of canalicular ATP binding cassette transporters in rat liver. J Biol Chem. 2001;276(10):7218-24.

39. Hawkins BT, Rigor RR, Miller DS. Rapid loss of blood-brain barrier P-glycoprotein activity through transporter internalization demonstrated using a novel in situ proteolysis protection assay. J Cereb Blood Flow Metab. 2010;30(9):1593-7.

40. McCaffrey G, Staatz WD, Sanchez-Covarrubias L, Finch JD, Demarco $\mathrm{K}$, Laracuente $\mathrm{ML}$, et al. P-glycoprotein trafficking at the blood-brain barrier altered by peripheral inflammatory hyperalgesia. J Neurochem. 2012;122(5):962-75.

41. Tome ME, Herndon JM, Schaefer CP, Jacobs LM, Zhang $Y$, Jarvis $C K$, et al. P-glycoprotein traffics from the nucleus to the plasma membrane in rat brain endothelium during inflammatory pain. J Cereb Blood Flow Metab. 2016:36(11):1913-28.

42. Tome ME, Jarvis CK, Schaefer CP, Jacobs LM, Herndon JM, Hunn KC, et al. Acute pain alters P-glycoprotein-containing protein complexes in rat cerebral microvessels: Implications for P-glycoprotein trafficking. J Cereb Blood Flow Metab. 2018;38(12):2209-22.

43. Barakat S, Demeule M, Pilorget A, Regina A, Gingras D, Baggetto LG, et al. Modulation of $\mathrm{p}$-glycoprotein function by caveolin-1 phosphorylation. J Neurochem. 2007:101(1):1-8.

44. Noack A, Noack S, Hoffmann A, Maalouf K, Buettner M, Couraud PO, et al. Drug-induced trafficking of p-glycoprotein in human brain capillary endothelial cells as demonstrated by exposure to mitomycin C. PLoS One. 2014;9(2):e88154.

45. Zhang F, Zhang H, Wang Z, Yu M, Tian R, Ji W, et al. P-glycoprotein associates with Anxa2 and promotes invasion in multidrug resistant breast cancer cells. Biochem Pharmacol. 2014;87(2):292-302.

46. Darby RA, Unsworth A, Knapp S, Kerr ID, Callaghan R. Overcoming ABCG2-mediated drug resistance with imidazo-[1,2-b]-pyridazine-based Pim1 kinase inhibitors. Cancer Chemother Pharmacol. 2015;76(4):853-64. 
47. Natarajan K, Bhullar J, Shukla S, Burcu M, Chen ZS, Ambudkar SV, et al. The Pim kinase inhibitor SGl-1776 decreases cell surface expression of P-glycoprotein (ABCB1) and breast cancer resistance protein (ABCG2) and drug transport by Pim-1-dependent and -independent mechanisms. Biochem Pharmacol. 2013:85(4):514-24.

48. Xie Y, Burcu M, Linn DE, Qiu Y, Baer MR. Pim-1 kinase protects P-glycoprotein from degradation and enables its glycosylation and cell surface expression. Mol Pharmacol. 2010;78(2):310-8.

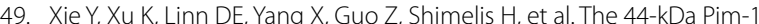
kinase phosphorylates BCRP/ABCG2 and thereby promotes its multimerization and drug-resistant activity in human prostate cancer cells. J Biol Chem. 2008;283(6):3349-56.
50. Chen D, Zhang H, Lu P, Liu X, Cao H. Synergy evaluation by a pathwaypathway interaction network: a new way to predict drug combination. Mol Biosyst. 2016;12(2):614-23.

51. Kuhn M. The microtubule depolymerizing drugs nocodazole and colchicine inhibit the uptake of Listeria monocytogenes by P388D1 macrophages. FEMS Microbiol Lett. 1998;160(1):87-90.

\section{Publisher's note}

Springer Nature remains neutral with regard to jurisdictional claims in published maps and institutional affiliations.
Ready to submit your research? Choose BMC and benefit from:

- fast, convenient online submission

- thorough peer review by experienced researchers in your field

- rapid publication on acceptance

- support for research data, including large and complex data types

- gold Open Access which fosters wider collaboration and increased citations

- maximum visibility for your research: over 100M website views per year

At BMC, research is always in progress.

Learn more biomedcentral.com/submissions 